\title{
Umberto Eco on the biosemiotics of Giorgio Prodi
}

\author{
Kalevi Kull \\ Department of Semiotics \\ University of Tartu \\ Jakobi 2, Tartu 51005, Estonia \\ e-mail: kalevi.kull@ut.ee
}

\begin{abstract}
The article provides a commentary on Umberto Eco's text "Giorgio Prodi and the lower threshold of semiotics". An annotated list of Prodi's English-language publications on semiotics is included.
\end{abstract}

Keywords: history of biosemiotics; lower semiotic threshold; medical semiotics

Biology is pure natural semiotics.

Prodi 1986b: 122

Is it by law or by nature that the image of Mickey Mouse reminds us of a mouse?

Eco 1999: 339

"When I discovered the research of Giorgio Prodi on biosemiotics I was the person to publish his book that maybe I was not in total agreement with, but I found it was absolutely important to speak about those things", Umberto Eco said during our conversation in Milan in 2012. Indeed, two books by Prodi - Orizzonti della genetica (Prodi 1979; series Espresso Strumenti) and La storia naturale della logica (Prodi 1982; series Studi Bompiani: Il campo semiotico) - appeared in series edited by Eco.

Giorgio Prodi was a biologist whom Eco highly valued, an expert and an encyclopedia for him in the fields of biology and medicine, a scholar whose work in biosemiotics Eco took very seriously. Eco spoke about this in a talk from 1988 (Eco 2018), saying that he had been suspicious of semiotic approaches to cells until he met Prodi in 1974. The latter's suggestion that instead of thinking whether cells 
speak like us, the question should be asked whether we speak like cells, struck him with its originality. As Eco describes Prodi's conclusions, he repeats upon reading Prodi's last article "La cultura come ermeneutica natural" (Prodi 1988d; in English "Culture as natural hermeneutics"- Prodi 1989b) that "hermeneutics is not a late product of culture, but the same elementary movement of life that is born because something obscurely interprets something else" (Eco 2018: 350). Eco adds that Prodi's "proposal remains a challenge that I do not think has been welcomed yet in all its implications" (Eco 2018: 350).

Eco's text just quoted above was found thanks to Thomas Sebeok's collection. In Sebeok's personal library in Bloomington (which now belongs to the Department of Semiotics of the University of Tartu), there was a fine collection of publications by Prodi, consisting of ten books and a set of reprints of his articles on semiotics. The pack of reprints included also Umberto Eco's manuscript titled as "Giorgio Prodi e la soglia inferiore della semiotica" ("Giorgio Prodi and the lower threshold of semiotics"). The typewritten manuscript is undated, although the references made in the text allow us to presume that this was the text of a talk given at an event in honour of Giorgio Prodi in 1988. The text was translated for Sign Systems Studies by Remo Gramigna and is published in English for the first time in this issue of the journal. We find this paper important in the context of Eco's search for limits of general semiotics and his views on biosemiotics, which is our focus here. ${ }^{1}$

\section{Prodi's publications}

Giorgio Prodi (1928-1987) was an Italian medical scientist, oncologist and semiotician from Bologna. He studied medicine and chemistry and conducted research in general pathology and experimental oncology, also teaching these disciplines. From 1973, he was the head of the Institute of Cancer Research. All this happened in Bologna (Prodi 1987) where he also wrote several books on philosophy of biology and medicine.

Prodi was asking semiotic questions concerning biology just at the time when Thomas Sebeok rediscovered Jakob von Uexküll - in the late 1970s. Yet there were only a few researchers in biosemiotics at that time; Sebeok met Prodi and became very supportive of his work. In a couple of his articles he recalls a week spent in the company of Thure von Uexküll and Giorgio Prodi in Freiburg in 1979:

Thure made arrangements for me to spend a week or so visiting him in Freiburg. [...] Our Freiburg discussions about multifarious biosemiotic topics were carried

For more on Eco's relationship with biosemiotics see Kull 2017; 2018 b. 
out, with rare intensity, from morning late into every night, and were happily augmented by the continuous participation of Giorgio Prodi, Director of the Institute for Cancer Research of the University of Bologna. Prodi, an astounding polymath [Eco 1988b] who had become my friend several years earlier, encountered Thure for the first time on that occasion; the two of them met only twice more, first in Palermo in the Summer of 1984, then the last time in Lucca ${ }^{2}$ in the early fall of 1986. (Sebeok 2004: 87-88)

Prodi's works from the 1970s and 1980s made him a co-founder of contemporary biosemiotics. Thomas Sebeok dedicated the first volume ever published under the title "Biosemiotics" to him, with the inscription "In memoriam: Giorgio Prodi (1928-1987): bold trailblazer of contemporary biosemiotics" (Sebeok, UmikerSebeok 1992: v). Donald Favareau included Prodi in his list of 24 essential authors on biosemiotics in the first ever anthology of biosemiotics (Favareau 2010a, 2010b; Prodi 2010a). Thus, Prodi is considered as a classic in the field. Felice Cimatti has written a monograph about Prodi (Cimatti 2000a; 2018; see also Cimatti 2000b; Kull 2018a).

Prodi was a very productive writer. In the bibliography of his publications (Prodi 1987) his works are divided into two categories. The category "scientific" includes ten books (all in Italian, except for one edited volume of conference proceedings in English) and 324 articles $^{3}$ (most of these in co-authorship, 178 in English, a few in French, the rest in Italian). The category "philosophical and literary" includes 13 books (all in Italian) and 66 articles (most of these singleauthored, six in English, the rest in Italian). Works on semiotics are all listed in this latter category. Thus almost everything Prodi wrote on the philosophy of biology, philosophy of medicine, and semiotics, is available only in Italian.

We can observe that Prodi's work has not been much used either in semiotics or in general biology or philosophy of biology, at least not outside of Italy - the language barrier might be an explanation here. Even Thure von Uexküll and Prodi do not seem to refer to each other explicitly in writing.

Prodi himself did not write much about other biosemiotic approaches already existing by the 1980s, either. Still, it seems to have been his style not to devote much energy to the discussions of other scholars' views, although he has mentioned some scholars in semiotics - Charles Sanders Peirce, Jakob von Uexküll, Charles Morris, Jean Piaget, Peter Marler, W. John Smith, ${ }^{4}$ Thomas A. Sebeok (Prodi 1983, 1988b).

\footnotetext{
2 For the volume of proceedings, see Sercarz et al. 1988.

3 The publication list starts from 1953.

4 Smith 1965.
} 
Prodi's first article on semiotics was titled "La preistoria del segno" ("The prehistory of sign") and it was published in 1974 (Prodi 1974). ${ }^{5}$ His books that are relevant to semiotics include Le basi materiali della significazione (Prodi 1977), Orizzonti della genetica (Prodi 1979), La storia naturale della logica (Prodi 1982), Teoria e metodo in biologia e medicina (Prodi 1988b), L'individuo e la sua firma: biologia e cambiamento antropologico (Prodi 1989e).

The complete list of Prodi's works on semiotics currently available in English is the following:

(1) "Material bases of signification", a long article published in Semiotica (Prodi 1988a). This is an abbreviated translation of Prodi 1977; the article with the same title "Le basi materiali della significazione", published in Versus in 1976, is a different text.

(2) "Development of semiosic competence", an article published in the Encyclopedic Dictionary of Semiotics (Prodi 1986a; reprinted in the next editions of the Encyclopedia - Prodi 1994, 2010b). The first version of this text - under the preliminary titles "Phylogeny of codes" and "Ontogeny of codes" - was written in 1981 (as mentioned in Prodi 1987: 60).

(3) "Biology as natural semiotics" (Prodi 1989c), an article published in a Bochum semiotics series; originally it was a talk given at the Third Congress of the International Association for Semiotic Studies in Palermo in 1984. ${ }^{6}$ An Italian version of this article has been re-published repeatedly (Prodi 1984, 1988e, 2002).

(4) "Culture as natural hermeneutics" (Prodi 1989b), an article published in the proceedings volume of the 1986 Bochum conference The Nature of Culture. An Italian version was published as Prodi 1988d.

(5) "Signs and codes in immunology", an article published in the volume of proceedings of the 1986 Lucca conference, The Semiotics of Cellular Communication in the Immune System (Prodi 1988c). Reprinted in Essential Readings in Biosemiotics (Prodi 2010a).

(6) "Toward a biologically grounded ethics" in the University of Bologna publication Alma Mater Studiorum (Prodi 1989d) is printed together with the Italian text, which was a talk given at the 1987 conference "Ethics of scientific knowledge" in Venice.

5 See also an interview with Prodi (Prodi 1986b).

6 Prodi attended also the Second Congress of the International Association for Semiotic Studies in Vienna in 1979, giving the talk "The origin of meaning in phylogenesis" (as mentioned in Prodi 1983: 202), but his paper was not published in the Congress proceedings (Borbé 1984). 


\section{Eco's references to Prodi}

When discussing the biological roots of semiosis, Eco repeatedly turned to Prodi.7 Describing Prodi's impact, he pointed out a major aim of biosemiotics:

[...] the assumption that both a genetic and an immunological code can in some sense be analysed semiotically seems to constitute the new scientific attempt to find a language that can be defined as a primitive par excellence, though not in historical, but rather in biological terms. This language would rest in the roots of evolution itself, stretching back to before the dawn of humanity. This was the thesis of our friend Giorgio Prodi ${ }^{8}$, published by Tom Sebeok even in English ${ }^{9}$. Just one remark, that in this last case Prodi was not looking for the historical origins of language, but rather for the biological roots of semiosis, which is a different approach. (Eco 2004: 27-28)

The role of Giorgio Prodi for Eco was noted by Thomas Sebeok, who, in his foreword to a book about Umberto Eco, devotes a notably lengthy passage to Giorgio Prodi (Sebeok 1997: xiv):

I do believe it is appropriate for me to note here [Umberto Eco's] involvement with yet another among our mutual friends, the late Giorgio Prodi (1928-1987), Eco's near-contemporary colleague at the University of Bologna, and himself the scion of a very distinguished family of Italian public servants and academics, severally close to Eco. Prodi was a prodigiously busy polymath, in some way outEcoing Eco: "Perché [Giorgio] aveva una giornata di quarantott'ore e noi di sole ventiquattro?", ${ }^{10}$ Umberto questioned in mock-peeve. Indeed, Prodi was, on the one hand, one of his country's leading medical biologists in oncology, while he was, on the other, a highly original contributor to semiotics and epistemology, the philosophy of language and formal logic, plus a noteworthy literary figure. An immensely prolific scientist, Prodi was one of a handful of European pioneers in the exploding transdisciplinary field that has come lately to be dubbed biosemiotics. The year before Prodi died, he and Eco together took part in a landmark meeting in Lucca, ${ }^{11}$ juxtaposing semiotics and immunology, bringing the two, as it were, under a new interdisciplinary branch of biological sciences, "immunosemiotics", which is now, with a different emphasis, an important branch of biosemiotics. Prodi's earliest contribution to this area, Le basi materiali della signi-

7 Eco mentiones Prodi in his acknowledgements to Kant e l'ornitorinco (Eco 1997; the English version of this book differs in some parts from the Italian, as is the case also with some other books on semiotics by Eco).

8 Reference to Prodi 1977.

9 Prodi 1988a; that is a partial translation of Prodi 1977.

10 "Why [Giorgio] had a day of forty-eight hours and we one of only twenty-four?".

11 See Eco 1988a and Prodi 1988c. 
ficazione, was published first in Ecos journal Vs (1976), ${ }^{12}$ then boldly the following year in one of the well-known Bompiani series also edited by him. ${ }^{13}$ Again, his beautiful, characteristically informed and observant Ricordo of Prodi's life and accomplishments, "Una sfida al mito delle due culture" [Eco 1988b], repays close study for what it tells us about Giorgio no less, to be sure, for what it reveals about Umberto.

The talk mentioned by Sebeok, which Eco dedicated to Prodi, "A challenge to the myth of the two cultures", has been published a couple of times (Eco 1988b and 1989; in English translation, Eco 1994). In this talk, Eco sides with Prodi in the latter's attempts to overcome the divide between humanities and sciences.

When discussing the genetic code as a possible example of s-code in his Semiotics and the Philosophy of Language (Ch. 5.7 "The genetic code"), ${ }^{14}$ Eco writes (Eco 1986: 183-184):

[The genetic] code looks like a system of equivalences (though between a unique content and synonymous expressions). But since the transcription ${ }^{15}$ takes place through a process of steric stimuli, one could describe the process as an instructional one. The protagonists of the whole process 'know' (by a sort of blind material wisdom) that, if a given series of stimuli is provided, then a given insertion must be performed. Prodi (1977) maintains that such a basic phenomenon represents an elementary, but by no means metaphorical, example of interpretation in Peirce's sense. Every element in the process interprets a previous one and, in doing so, makes the process grow. A case of semiosis, even though not unlimited.

Eco (1986: 184) continues to say:

Thus the genetic code (but this time we can speak of the one of the organism, not only of the one of geneticists) seems to be an s-code made up with minor $\mathrm{s}$-codes, in which every element is definable in terms of its (steric) position and

\footnotetext{
12 Another article by Prodi in Versus - "L'interpretazione come cambiamento dell'interprete" ("Interpretation as a change of the interpreter") - was published posthumously as Prodi 1989a. 13 Prodi 1977.

14 Eco defines s-code as a semiotic structure (Eco 1976: 38-40).

15 While he is using the word 'transcription' here, what Eco actually means is called 'translation' in terms of molecular biology. This becomes apparent in the figure on the previous page (Eco 1986: 183) which depicts the correspondence between nucleotide triplets and aminoacids (which is indeed the genetic code, based on the process of translation), while 'transcription' refers to the correspondence of nucleotides between strands of DNA and RNA. Eco refers to both terms, but the important difference (from a biosemiotic point of view) between these processes (translation being mediated and thus historical, while transcription being nonmediated and purely sterical) remains unnoticed by Eco - and seemingly also by Prodi.
} 
opposition to other elements, but also a code in the strong sense of the term, both correlational and institutional, where not only $x$ correponds to $y$, but where also if $x$ then $y$ must be realized. More similar to a mathematical system than to a judicial deontic code, ruled by necessity, susceptible obviously to errors (mutations, cancer), but not optional.

The fruitfulness of the genetic metaphor is not due to the fact that it can say whether the genetic processes are semiotic or not. What the metaphor reveals is that, even at the elementary level of these biological phenomena, there is no sensible difference (a) between s-codes and codes and (b) between correlation and instruction - that is, there is no sensible difference between equivalence and inference, each equivalence being a quasi-automatic inference.

Still, it should be possible to make a distinction whether the automatic or quasiautomatic inference has been created as a product of semiosis (based on optionality) and requires mediation in order to persist (in which case the term 'inference' is appropriate), or if it is directly steric indeed, in which case the earlier semiosis plays no role in its occurrence. Eco (1986: 184) concludes:

Maybe it is too hard to assume (as Prodi suggests; see $1983^{16}$ ) that the bio-logic represents the model, the source, and the materialistic foundation of the "cultural" logic, and therefore of every semiotics. It is certain, however, that when studying both bio-logic and conceptual logic we are in trouble when we try to distinguish correlation from instruction, s-codes from codes. Or, to put it in more reasonable terms, we can outline theoretical distinctions, by elaborating different abstract models, but we are obliged to recognize that in the actual semiosis these models are instantiated all together at the same time. Which explains (even though maybe it does not completely legitimize) the "generous" use of code made by so many disciplines in the last decades.

In Kant and the Platypus, Umberto Eco introduces an explicit theoretical connection between his searches and Prodi's:

I am admitting with Prodi (1977) that to understand the higher cultural phenomena, which clearly do not spring from nothing, it is necessary to assume that certain "material bases of signification" exist, and that these bases lie precisely in this disposition to meet and interact that we can see as the first manifestation (not yet cognitive and certainly not mental) of primary iconism. (Eco 1999: 107)

This occurs in the chapter titled "The lower threshold of primary iconism" (Eco 1999: 106-112). Trying again to solve the problem of the limit of semiotics, Eco thinks of Prodi, yet he goes further than ten years earlier, when he spoke about the

16 Eco obviously means Prodi 1982, since there is no Prodi 1983 in his list of references. 
lower threshold in his talk in honour of Prodi (Eco 2018 [1988]). He turns to holes, to absence - from which recognition begins. The same idea has been developed by Terrence Deacon - first very briefly mentioned in The Symbolic Species, ${ }^{17}$ and then extensively explored in Incomplete Nature. But still, Eco has no confidence in the identification of the threshold. What he is searching for is interpretation that makes up choice. If Prodi had made a clear distinction between mediated and direct recognition - this is what is so different between the processes of translation and transcription in the cell - then also Eco could have seen a qualitative difference between these types of interaction. However, Prodi's ontology did not seem to use enough distinctions at that point to be able to make a real agreement - or even a joint discovery - with Eco on the scope of interpretation, of semiosis and of the products of semiosis. That last point - the ontology used by Prodi - is commented on by Felice Cimatti in his monograph about Prodi (Cimatti 2018).

Thus we can agree with Eco when he warns us:

With all due caution: in no way am I repudiating the distinction (which remains fundamental) between signal and sign, between dyadic processes of stimulusresponse and triadic processes of interpretation, so that only in the full expansion of this last do phenomena such as signification, intentionality, and interpretation (however you wish to consider them) emerge. (Eco 1999: 107)

The origin of irreducible triadicity, or the necessary and sufficient conditions for semiosis, has been widely studied and discussed in semiotics (see, e.g., Alač, Violi 2004; Nöth 1994; Merrell 2013, etc.). In the field of biosemiotics these questions have received a whole variety of proposed answers (Hoffmeyer 1996, 2009; Pattee 2001; Deacon 2011; Barbieri 2007; Emmeche, Kull 2011; Maran et al. 2011; Sharov 2013, 2017; Sharov, Vehkavaara 2015; etc.).

Nevertheless, a fundamental question still remains about the movement between semiosis and non-semiosis, or signs and non-signs. This question is not removed by the distinction between proto-signs and eu-signs, as the usage of the term protosign or proto-semiosis is justified only if proto-semiosis is semiosis in some sense. A solution proposed for this problem turns attention to the interdependent and simultaneous existence of possibilities and the process of choice. Interpretation (which is semiosis, according to Peirce) assumes a choice between possibilities, i.e. optionality. The existence of choice and options as necessary conditions for interpretation and semiosis is also used by Umberto Eco (e.g., Eco 2018) as an argument for the limits of the domain of semiotics.

17 See the motto from Lao Tsu to Chapter 14 in Deacon 1997: 433. 
A choice that an interpretation makes is the mechanism that introduces semiotic order in the form of habits or codes - i.e. the local relations, produced by semiosis. Habits and codes working automatically can be described as incomplete semiosis, or relations without semiosis, which keep the order introduced earlier by semiosis. However, as products of semiosis, such relations can be (and have been) a research object for semiotics. Only if proto-signs as described by Prodi and others are products of earlier triadic semiosis is it justified to apply semiotic models in order to describe them. A careful analysis of ontological assumptions made by semioticians is an important task in biosemiotic research, helping to discover the scope of applicability of semiotics. The boundary between the semiosic and the non-semiosic is not describable as one binary opposition, it includes steps, and thus it is appropriate to speak about the semiotic threshold zone instead of just the threshold (Kull et al. 2009; Rodríguez Higuera, Kull 2017).

In contemporary Italy, courses in semiotics are taught at almost every university, while the role of biosemiotics in these is still small. In this context, it is interesting to see how Cimatti (2018) describes the relationship of Prodi's philosophy to Italian theory (or Italian thought) as this concept has recently been explicated (Esposito 2015; Gentili 2012; Claverini 2016). Indeed, the understanding of a certain broad domain, and the ways in which the understanding is expressed, bear also a certain local cultural trace. ${ }^{18}$

\section{References}

Alač, Morana; Violi, Patrizia (eds.) 2004. In the Beginning: Origins of Semiosis. (Semiotic and Cognitive Studies 12.) Bologna: Brepols.

Barbieri, Marcello (ed.) 2007. Introduction to Biosemiotics: The New Biological Synthesis. Berlin: Springer.

Borbé, Tasso (ed.) 1984. Semiotics Unfolding: Proceedings of the Second Congress of the International Association for Semiotic Studies, Vienna, July 1979. 3 vols. (Approaches to Semiotics 68.) Berlin: Mouton de Gruyter.

Cimatti, Felice 2000a. Nel segno del cerchio: Lontologia semiotica di Giorgio Prodi. Roma: Il manifesto Libri.

- 2000b. The circular semiosis of Giorgio Prodi. Sign Systems Studies 28: 351-379.

- 2018. A Biosemiotic Ontology: The Philosophy of Giorgio Prodi. (Biosemiotics 18.) Berlin: Springer. [English edition of Cimatti 2000a.]

18 Acknowledgements. I thank Remo Gramigna for his help in preparing the section about Umberto Eco in this issue of Sign Systems Studies, Felice Cimatti for inspiration, and EneReet Soovik for her help in editing the text. This work was supported by institutional research funding IUT2-44 of the Estonian Ministry of Education and Research. 
Claverini, Corrado 2016. La loso a italiana come problema: Da Bertrando Spaventa all'Italian Theory. Giornale Critico di Storia delle Idee 15/16: 179-188.

Deacon, Terrence W. 1997. The Symbolic Species: The Co-evolution of Language and the Brain. New York: W. W. Norton \& Co.

- 2011. Incomplete Nature: How Mind Emerged from Matter. New York: W. W. Norton \& Co.

Eco, Umberto 1976. A Theory of Semiotics. Bloomington: Indiana University Press.

- 1986[1984]. Semiotics and the Philosophy of Language. Bloomington: Indiana University Press.

- 1988a. On semiotics and immunology. In: Sercarz, Eli E.; Celada, Franco; Michison, N. Avrion; Tada, Tomio (eds.) 1988. The Semiotics of Cellular Communication in the Immune System: Proceedings of the NATO Advanced Research Workshop on the Semiotics of Cellular Communication in the Immune System held at Il Ciocco, Lucca, Italy, September 9-12, 1986. (Nato ASI Series 23.) Berlin: Springer, 3-15.

- 1988b. Una sfida al mito delle due culture. Saecularia nona: 46-49. [In English: Eco 1994.]

- 1989. Una sfida al mito delle due culture. Il Belpaese 7: 166-168. [Reprint of Eco 1988b.]

- 1994. In memory of Giorgio Prodi: A challenge to the myth of two cultures. (Johnston, Marina, trans.) In: Jaworski, Leda Giannuzzi (ed.), Lo studio bolognese: campi di studio, di insegnamento, di recerca, di divulgazione. (Filibrary series 8.) Stony Brook: Forum Italicum (Center for Italian Studies, State University of New York at Stony Brook), 75-78. [Translation of Eco 1988b.]

- 1997. Kant e l'ornitorinco. (Studi Bompiani: Il campo semiotico.) Milano: Bompiani.

- 1999[1997]. Kant and the Platypus: Essays on Language and Cognition. (McEwen, Alastair, trans.) San Diego: A Harvest Book, Harcourt.

- 2004. Origins of semiosis. In: Alač, Morana; Violi, Patrizia (eds.), In the Beginning: Origins of Semiosis. (Semiotic and Cognitive Studies 12.) Bologna: Brepols, 25-30.

- 2018. Giorgio Prodi and the lower threshold of semiotics. Sign Systems Studies 46(2/3): 343-351. [Original: Giorgio Prodi e la soglia inferiore della semiotica. (N.d., probably 1988.) Manuscript in the T. A. Sebeok Memorial Library, Department of Semiotics, University of Tartu, Estonia.]

Emmeche, Claus; Kull, Kalevi (eds.) 2011. Towards a Semiotic Biology: Life is the Action of Signs. London: Imperial College Press.

Esposito, Roberto 2015. German philosophy, French theory, Italian thought. In: Gentili, Dario; Stimilli, Elettra (eds.) 2015. Differenze italiane. Politica e loso a: mappe e sconnamenti. Roma: DeriveApprodi, 9-20.

Favareau, Donald (ed.) 2010a. Essential Readings in Biosemiotics: Anthology and Commentary. (Biosemiotics 3.) Berlin: Springer.

- 2010b. Introduction and commentary: Giorgio Prodi (1928-1987). In: Favareau, Donald (ed.), Essential Readings in Biosemiotics: Anthology and Commentary. (Biosemiotics 3.) Berlin: Springer, 323-327.

Gentili, Dario 2012. Italian Theory: Dalloperaismo alla biopolitica. Bologna: Il Mulino.

Hoffmeyer, Jesper 1996. Signs of Meaning in the Universe. Bloomington: Indiana University Press.

- 2009. Biosemiotics: An Examination into the Signs of Life and the Life of Signs. Scranton: University of Scranton Press.

Kull, Kalevi 2017. On the limits of semiotics, or the thresholds of/in knowing. In: Thellefsen, Torkild; Sørensen, Bent (eds.), Umberto Eco in His Own Words. (Semiotics, Communication and Cognition 19.) Berlin: De Gruyter Mouton, 41-47. 
- 2018a. Biosemiotics by Giorgio Prodi: A postscript. In: Cimatti, Felice, A Biosemiotic Ontology: The Philosophy of Giorgio Prodi. (Biosemiotics 18.) Berlin: Springer, 137-149.

- 2018b. A study by Umberto Eco and his colleagues on the history of early zoosemiotics: Commentary and bibliography. Sign Systems Studies 46(2/3): 383-391.

Kull, Kalevi; Deacon, Terrence; Emmeche, Claus; Hoffmeyer, Jesper; Stjernfelt, Frederik 2009. Theses on biosemiotics: Prolegomena to a theoretical biology. Biological Theory: Integrating Development, Evolution, and Cognition 4(2): 167-173.

Maran, Timo; Martinelli, Dario; Turovski, Aleksei (eds.) 2011. Readings in Zoosemiotics. (Semiotics, Communication and Cognition 8.) Berlin: De Gruyter Mouton.

Merrell, Floyd 2013. Meaning Making: It's What We Do; It's Who We Are. (Tartu Semiotics Library 12.) Tartu: University of Tartu Press.

Nöth, Winfried (ed.) 1994. Origins of Semiosis: Sign Evolution in Nature and Culture. (Approaches to Semiotics 116.) Berlin: Mouton de Gruyter.

Pattee, Howard Hunt 2001. The physics of symbols: Bridging the epistemic cut. Biosystems 60: $5-21$.

Prodi, Giorgio 1974. La preistoria del segno. Lingua e Stile 9(1): 117-145.

- 1976. Le basi materiali della significazione. Versus 13: 69-93.

- 1977. Le basi materiali della significazione. (Nuovi saggi italiani 21.) Milano: Bompiani.

- 1979. Orizzonti della genetica. (Espresso Strumenti 6, a cura di Umberto Eco.) Roma: Editoriale l'Espresso.

- 1982. La storia naturale della logica. (Studi Bompiani: Il campo semiotico, a cura di Umberto Eco.) Milano: Bompiani.

- 1983. Linguistica e biologia. In: Segre, Cesare (ed.), Intorno alla linguistica. Milano: Feltrinelli, 172-202. [Discussion on the article pp. 308-319.]

- 1984. La biologia come semiotica naturale. Il Protagora 24(6): 85-104. [In a special issue of the journal: Bonfantini, Massimo A.; Ferraresi, Mauro (eds.), La ragione abduttiva.]

- 1986a. Semiosic competence, development of. In: Sebeok, Thomas A. (ed.), Encyclopedic Dictionary of Semiotics. Vol 2, N-Z. (Approaches to Semiotics 73.) Berlin: Mouton de Gruyter, 884-887.

- 1986b. [Interview.] In: Marrone, Gianfranco (ed.), Dove va la semiotica? (Quaderni del Circolo Semiologico Siciliano 24.) Palermo: Circolo Semiologico Siciliano.

- ca 1987. Curriculum vitae ed elenco delle pubblicazioni. [62 pp. +5 pp. with an additional list from 1988-1990. A copy at the T. A. Sebeok Memorial Library, Department of Semiotics, University of Tartu.]

- 1988a[1977]. Material bases of signification. Semiotica 69(3/4): 191-241.

- 1988b. Teoria e metodo in biologia e medicina. Bologna: Editrice CLUEB.

- 1988c. Signs and codes in immunology. In: Sercarz, Eli E.; Celada, Franco; Michison, N. Avrion; Tada, Tomio (eds.) 1988. The Semiotics of Cellular Communication in the Immune System: Proceedings of the NATO Advanced Research Workshop on the Semiotics of Cellular Communication in the Immune System held at Il Ciocco, Lucca, Italy, September 9-12, 1986. (Nato ASI Series 23.) Berlin: Springer, 53-64.

- 1988d. La cultura come ermeneutica naturale. Intersezioni, Rivista di storia delle idee (Bologna: Società Editrice Il Mulino) 8(1): 23-48. [English translation in Prodi 1989b.]

- 1988e. La biologia come semiotica naturale. In: Herzfeld, Michael; Melazzo, Lucio (eds.), Semiotic Theory and Practice: Proceedings of the Third International Congress of the IASS Palermo, 1984. Vol. 2. Berlin: Mouton de Gruyter, 929-951. 
- 1989a. L'interpretazione come cambiamento dell'interprete. Versus 52/53: 21-24.

- 1989b. Culture as natural hermeneutics. In: Koch, Walter A. (ed.), The Nature of Culture. Proceedings of the International and Interdisciplinary Symposium, October 7-11, 1986 in Bochum. (Bochum Publications in Evolutionary Cultural Semiotics; BPX 12.) Bochum: Studienverlag Dr. Norbert Brockmeyer, 215-239. [Translation of Prodi 1988d.]

- 1989c. Biology as natural semiotics. In: Koch, Walter A. (ed.), For a Semiotics of Emotion. (Bochumer Beiträge zur Semiotik; BBS 4.) Bochum: Brockmeyer, 93-110.

- 1989d. Toward a biologically grounded ethics. Alma Mater Studiorum 2(1): 65-73.

- 1989e. L'individuo e la sua firma: biologia e cambiamento antropologico. Bologna : Il Mulino.

- 1994. Semiosic competence, development of. In: Sebeok, Thomas A. (ed.), Encyclopedic Dictionary of Semiotics. Vol 2, N-Z. 2nd ed. (Approaches to Semiotics 73.) Berlin: Mouton de Gruyter, 884-887. [Reprint of Prodi 1986a.]

- 2002. La biologia come semiotica naturale. Athanor 5: 63-72.

- 2010a. Signs and codes in immunology (1988). In: Favareau, Donald (ed.), Essential Readings in Biosemiotics: Anthology and Commentary. (Biosemiotics 3.) Berlin: Springer, 328-335. [Reprint of Prodi 1988c.]

- 2010b. Semiosic competence, development of. In: Sebeok, Thomas A.; Danesi, Marcel (eds.), Encyclopedic Dictionary of Semiotics. Vol 2, N-Z. 3rd ed. Berlin: De Gruyter Mouton, 907910. [Reprint of Prodi 1986a.]

Rodríguez Higuera, Claudio Julio; Kull, Kalevi 2017. The biosemiotic glossary project: The semiotic threshold. Biosemiotics 10(1): 109-126.

Sebeok, Thomas A. 1997. Foreword. In: Capozzi, Rocco (ed.), Reading Eco: An Anthology. Bloomington: Indiana University Press, xi-xvi.

- 2004. Origins: Semiosis the domain vs. Semiotics the field. In: Alač, Morana; Violi, Patrizia (eds.), In the Beginning: Origins of Semiosis. (Semiotic and Cognitive Studies 12.) Bologna: Brepols, 83-104.

Sebeok, Thomas A.; Umiker-Sebeok, Jean (eds.) 1992. Biosemiotics: Semiotic Web 1991. (Approaches to Semiotics 106.) Berlin: Mouton de Gruyter.

Sercarz, Eli E.; Celada, Franco; Michison, N. Avrion; Tada, Tomio (eds.) 1988. The Semiotics of Cellular Communication in the Immune System: Proceedings of the NATO Advanced Research Workshop on the Semiotics of Cellular Communication in the Immune System held at Il Ciocco, Lucca, Italy, September 9-12, 1986. (Nato ASI Series 23.) Berlin: Springer.

Sharov, Alexei 2013. Minimal mind. In: Swan, Liz (ed.), Origins of Mind. (Biosemiotics 8.) Dordrecht: Springer, 343-360.

- 2017. Molecular biocommunication. In: Gordon, Richard; Seckbach Joseph (eds.), Biocommunication: Sign-Mediated Interactions between Cells and Organisms. New Jersey: World Scientific, 3-35.

Sharov, Alexei; Vehkavaara, Tommi 2015. Protosemiosis: Agency with reduced representation capacity. Biosemiotics 8(1): 103-123.

Smith, W. John 1965. Message, meaning, and context in ethology. The American Naturalist 99(908): 405-409. 
364 Kalevi Kull

\section{Умберто Эко о биосемиотике Джорджио Проди}

Комментария к тексте Умберто Эко «Джорджио Проди и нижний семиотический порог». Включен список публикаций Проди о семиотике которые существуют на английском языке.

\section{Umberto Eco Giorgio Prodi biosemiootikast}

Esitatakse kommentaar Umberto Eco tekstile “Giorgio Prodi ja semiootika alumine lävi”. Lisatud on Prodi ingliskeelsete semiootika-alaste publikatsioonide loend. 